\title{
THE IMPACT OF THE LEVEL OF ECONOMIC DEVELOPMENT ON FOOD CONSUMPTION IN POLAND
}

\author{
Joanna Szwacka-Mokrzycka ${ }^{1}$
}

${ }^{1}$ Warsaw University of Life Sciences - SGGW

\begin{abstract}
The article presents the directions of the development of food consumption in Poland in view of the changes occurring in the EU. The aim of this paper is to identify the relationship between the level of economic development of a country and the consumers' standard of living. The starting point of the discussion is an interdisciplinary presentation of the current development of the theory of consumption. Next, the changes in food consumption in Poland are presented against the background of general European trends in 2009-2015. The explored trends include both the quantitative and qualitative transformations in the amounts and structure of food consumption. This paper was developed based on secondary information sources published by the Polish Central Statistical Office (GUS) and Eurostat. It has been shown that the presented direction of changes follows in step of the research in this field performed during the last 15 years.
\end{abstract}

Key words: food consumption in Poland, level of economic development, food expenses, trends in consumption changes.

JEL code: Q13

\section{Introduction}

The success of Poland in the EU is being undeniably demonstrated by its position among the European Union leaders. It is reflected by the high level of economic growth, which reached $3.3 \%$ of GDP, with the European average of $1.3 \%$. What is more, Poland is the only EU country which has shown no signs of recession since 2003. Clearly, the success of Poland mostly results from the use of European funds.

Regarding the changes in food consumption associated with the socio-economic development, the accompanying increase in consumers' income leads, on the one hand, to a relative decrease of the share of expenditure on food in the total expenditure structure (Engel's law), but on the other hand, to changes in the level and structure of food consumption. One could venture that the segment of buyers of high quality food produced with ecological methods is becoming increasingly important in the food market in Poland.

The verification of Engel's law is of interest to many scientists, which has been reflected in numerous Polish and foreign studies (Zielinska, 1978; Szwacka-Salmonowicz, 2003; SzwackaMokrzycka, 2013; Kwasek, 2012; Janos-Kresło, Mroz, 2006).

The chief aim of this paper is to identify the relationship between the level of economic development of a country and the consumers' standard of living.

\section{Research results and discussion}

\section{The current knowledge of consumption science}

Consumption is an interdisciplinary subject. Many other fields, such as economy, sociology, psychology, and management contribute to it. The theory of consumption and its interpretation are also firmly anchored in marketing management. We shall include here both the objective and subjective approaches within the established market relations and their implementation using marketing instruments. In practice, various approaches to analysing consumption reveal its interdisciplinarity, which is illustrated by the analysis of the economic and sociological approaches in particular, leading to defining consumption as a socio-economic category (Bylok 2013). The treatment of consumption in the field of economy is grounded in the needs and the hierarchy and methods of their realisation (Maslow, 1990). From the perspective of the discussed economic context, the methods of fulfilment of consumption needs are also important. With regard to the 
mechanisms of market economy, there is no doubt that the realisation of needs takes place mostly through goods and services purchased through market exchange. It is reflected in the definition suggested by Bywalec \& Rudnicki, who demonstrated that "consumption is an act of fulfilling human needs through the use of material goods and services" (Bywalec, Rudnicki, 2002). The deliberation on this topic leads to the conclusion that the process of consumption is deeply rooted in culture and society. A broad reference to such an approach to consumption can be found in Szczepanski, who stresses the "(...) definition of consumption as a process of social reproduction and a sphere of social cooperation, comprising (...) conditions of social life: working conditions, standard of living of the community, consumption fund" (Szczepanski, 1981). Whereas in the sociological approach to consumption it is the social nature of human needs which is underlined. What we mean are the higher order needs, which appear as the society grows. The emergence and development of these needs are particularly affected by the social environment and the used forms and means of communication.

Over the last 15 years, the consumption science mostly focused on the processes of integration and globalisation of the world economy. Many researchers in this field studied the issues of new trends in consumption and the creation of a new consumer culture associated with it (Komor 2000; Mazurek-Lopacinska, 2003; Bywalec, 2010; Tkaczyk, 2012; Koszewska, 2013; Dabrowska, Bylok, Janos-Kreslo, Kielczewski, Ozimek, 2015; Malysa-Kaleta, 2015). The position of food consumption sciences began to form in the 1970s. Zielinska (1978) was the founder of these studies, followed by Janos-Kreslo (1989), Szwacka-Salmonowicz (1996), Żelazna (2000), Szwacka-Salmonowicz (2003), Gutkowska, Ozimek (2005), Urban (2005), Szwacka-Mokrzycka (2015), and many other scientists.

\section{The level of economic development of Poland compared to the EU}

It should be noted that the global crisis of 2008 and 2009 negatively affected the economic situation of the European Union Member States. In Poland, the GDP dynamics slowed as well, yet in 2009 it remained positive, at the level of $1.6 \%$ (Szwacka-Mokrzycka, 2015). Whereas in the remaining EU Member States, the downward trend could not be reversed. In the following years, 2010-2011, while the GDP growth dynamics in the EU countries stayed at the level of 1.8 and 1.3, it significantly exceeded these numbers in Poland, where the numbers for 2010 and 2011 were $3.8 \%$ and $3.9 \%$ respectively. It ensued from the noticeable reduction in the negative consequences of the economic crisis in Poland in 2010 due to increased economic activity. In the subsequent years, however, the GDP growth dynamics in Poland slowed following the economic recession of the first half of 2013. It was a result of a combination of the following factors: limited private investment due to economic slowdown, more difficult access to credit, restrictive fiscal policy, and a decrease in the propensity to consume (Szwacka-Mokrzycka, 2013). The following year 2014 showed a significant improvement in the economic situation of all EU Member States, albeit with a large variation in their GDP growth rates compared to 2013. In 2014, Poland ranked in the group of countries with relatively high growth rates, i.e., $3.4 \%$ compared to the previous year. The group of countries with relatively highest growth rates, above $3 \%$, included the following states: Ireland, Hungary, Luxembourg, Malta, and the United Kingdom. Conversely, a relatively small GDP growth rate in 2014 compared to 2013, namely below $2 \%$, was observed in Belgium, Denmark, Germany, Greece, Spain, and the Netherlands. Finland, Italy, Cyprus, and Croatia, however, failed to reverse the downward trend. 
The GDP growth rate in Poland corresponds to its position in Europe (among the developing countries).

Actual Individual Consumption and GDP in EU in $2016 \mathrm{EU}-28=100$, real prices

\begin{tabular}{|c|c|c|}
\hline Specification & AIC* per capita & GDP per capita \\
\hline EU & 100 & 100 \\
\hline Luxembourg & 132 & 267 \\
\hline Germany & 122 & 123 \\
\hline Austria & 118 & 126 \\
\hline United Kingdom & 115 & 108 \\
\hline Denmark & 114 & 125 \\
\hline Finland & 114 & 109 \\
\hline Belgium & 113 & 118 \\
\hline France & 111 & 105 \\
\hline Netherlands & 111 & 128 \\
\hline Sweden & 111 & 124 \\
\hline Ireland & 97 & 177 \\
\hline Italy & 97 & 96 \\
\hline Cyprus & 90 & 81 \\
\hline Spain & 89 & 92 \\
\hline Lithuania & 86 & 75 \\
\hline Portugal & 82 & 77 \\
\hline Malta & 81 & 95 \\
\hline Czech Republic & 78 & 88 \\
\hline Greece & 77 & 67 \\
\hline Slovakia & 77 & 77 \\
\hline Poland & 75 & 69 \\
\hline Slovenia & 75 & 83 \\
\hline Estonia & 71 & 74 \\
\hline Latvia & 67 & 65 \\
\hline Hungary & 63 & 67 \\
\hline Romania & 63 & 59 \\
\hline Croatia & 59 & 59 \\
\hline Bulgaria & 53 & 48 \\
\hline
\end{tabular}

AIC - Actual Individual Consumption, measured per inhabitant in PPS units

PPS - Purchasing Power Standard, an artificial currency used by Eurostat to express the actual GDP levels, to eliminate the influence of price differences between countries

Source: Eurostat Newsrelease, 91/2017/13 June 2017

It is necessary to point out the wide range of Actual Individual Consumption (AIC) and Gross Domestic Product (GDP) levels across the EU countries, which differ from the EU average between $53 \%$ and $132 \%$ (Table 1). The relatively highest rates were achieved by Luxembourg, Germany, Austria, the UK, Denmark, Finland, and Italy (32-20\% above the average for the EU). Whereas the relatively lowest rates belonged to Estonia, Latvia, Romania, and Hungary, 30-40\% below the EU average. Poland ranked in the group of countries (the Czech Republic, Greece, Slovakia, Slovenia, Poland) with the rates from $20 \%$ to $25 \%$ below the EU average (Table 1 ).

The effects accompanying the increased economic growth rate in Poland result from the integration with the European Union. The Polish accession to the EU enabled the development and modernisation of the economy due to increased investment size, new technologies, facilitated access to the markets of other member states, greater scale and specialisation of production, 
improved quality and effectiveness of management. The integration also accelerated the flow of direct foreign investments. Integration processes have a particularly strong impact on trade volumes. The free movement of goods entails not only a customs union and elimination of nontariff barriers but also improved conditions for our producers-exporters. Both the increased export dynamics and import absorption are results of the accession.

The influence of the integration processes on the transformation of the food economy is long term and stems from the need to adjust to the EU. The incorporation of the world economics into globalisation processes led to a polarisation of businesses into transnational corporations and subcontractors.

The transformations of food economy in Poland have been taking place under the influence of global companies involved in processing and trade.

\section{Food consumption in Poland - trends}

With regard to the food market, the principles established by Keynes and Engel, which refer to the regularities in income spending and involve changing the general relationship in the consumption expenditures and savings as well as changing the structure of expenses, have been confirmed multiple times. According to Keynes' law, as the income grows, so does the proportion of general consumption spending in total expenses decrease. Whereas in the light of Engel's law, the proportion of food expenses decreases with the growth of income. Regarding the changes in food consumption associated with the socio-economic development, the accompanying increase in consumers' income leads, on the one hand, to a relative decrease of the share of spending on food in the total expenditure structure (Engel's law), as well as to changes in the level and structure of food consumption on the other. It is expressed by the decreasing share of spending on absolutely basic and basic food products (cereal products, potatoes, animal fat), with a relatively increased share of spending on luxury food products (finer meat types, fresh and processed fruit and vegetables). The trend outlined so is accompanied by increased spending on food services both away from home and delivered home (catering).

What is important for these deliberations is how they relate go an empirical verification of Engel's law. It is according to Engel's coefficients, which relate spending on food to total expenditure, that the living standards of the society are evaluated. The more relatively low the coefficient, the higher the living standard of the studied social group. Conversely, a large share of spending on food in the total spending indicates unfavourable material conditions of a given social group. The studies to verify Engel's law have been of interest to many scientists, which is shown by numerous Polish and foreign publications (Zielinska, 1978; Szwacka-Salmonowicz, 2003; SzwackaMokrzycka, 2013; Kwasek, 2012; Janos-Kreslo, Mroz, 2006). The studies carried out in this area show that, in the first decade of the 21st century, there was a visible stimulation of transformations which involved increased saturation of food needs, qualitative transformations, and substitutive processes. It is demonstrated by an evident decrease in the income elasticity coefficients of food consumption, particularly in relation to basic food products. Whereas the demand for highly processed goods remains at a relatively high level. Hence, it can be assumed that household incomes are still a crucial determinant of the proximity between the transforming countries and the most developed countries of the EU.

When analysing the consumption expenditures of households in Poland in 2009-2015, a trend for a relative decrease in the proportion of food expenditure in the total expenditure structure can 
be observed. It results from the changes in consumption associated with the growing living standard of the society (Table 2 ).

Average total monthly expenditures of households in Poland in 2009-2015

(in PLN per person)

\begin{tabular}{|l|c|c|c|}
\hline \multicolumn{1}{|c|}{ Household type } & $\mathbf{2 0 0 9}$ & $\mathbf{2 0 1 1}$ & $\mathbf{2 0 1 5}$ \\
\hline Total expenditure & 956.68 & 1015.12 & 1091.19 \\
\hline Expenditure on consumer goods and services & 913.86 & 971.83 & 1042.91 \\
\hline Expenditure on food and non-alcoholic beverages & 240.08 & 254.13 & 262.32 \\
\hline Share of expenditure on food in total expenditure ( \%) & $25 \%$ & $25 \%$ & $24 \%$ \\
\hline
\end{tabular}

Source: author's calculations based on Budgets of Households (2016)

In the light of the data compiled in Table 2, it can be stated that the total expenditures of households increased in 2009-2015. The observed trend also includes expenditures on food and non-alcoholic beverages. Simultaneously, it should be noted that since food expenditures in the 2010s grew much more slowly than total expenditures, their total share decreased over the analysed period from $25.0 \%$ in 2009 to $24.0 \%$ in 2015 . These data confirm the general trend observed with regard to the member states of the EU. Referring the observed trend to the results of studies carried out in the EU-28 countries, it should be stated that in 2013-2014 the share of food expenditure in the total expenditure was similar in the developing countries and in Poland (Szwacka-Mokrzycka, 2015). Significantly lower values were reported for highly developed countries, where this share remained relatively small, at the same time being highly diversified depending on the studied country. As stated previously, it is associated with the levels of economic development and citizens' wealth. It can be assumed that the increase in the expenditure on consumer goods and services in Poland was moderate compared to the remaining EU countries. The prices of consumer goods and services are still highly diversified within the EU, indicative of their strong correlation with the level of economic growth and the purchasing power of the citizens of each country. The analysis of the data from the recent years reveals that, compared to the remaining EU countries, food prices are relatively lowest is Poland, Bulgaria, and Romania, and relatively highest in Austria, Denmark, and Sweden (Eurostat Newsrelease, 2016).

Changes in the level and structure of consumption are associated with many factors, both economic and social (Matuszewska, 1992). In literature, the determinants of the food market are usually divided into economic, social, psychological, and marketing-related (Szwacka-Salmonowicz, 2003). The adopted division has been closely related to the nature of the products which fulfil the dietary needs of consumers. It has been empirically demonstrated that, in the market of basic food products, the economic and social factors are of utmost importance. Whereas in the market of luxury food products, the significance of psychological and marketing-related factors is increasing.

The development of food consumption in Poland fits into the food economy model based on the two main paradigms of sustainable growth and globalisation. The paradigm of sustainable development emerges form the economy based on small-scale farms, which serve both economic and social functions. It is built on multi-directionalaims - regarding food production, fulfilling social and cultural needs, and caring for the natural environment. It is a response to the present-day demands of the food economy, where it is crucially important to entirely fulfil the needs of the consumer with a particular focus on its qualitative aspect. The evolution of the sustainable development paradigm is closely related to the ecological movement (with its origins in the 1970s), evoking the ethics of the natural environment and marking a secure path for creating the consumer 
behaviours of ecologically aware societies. The development of food consumption in the globalisation paradigm has strong internationalising connotations. Globalisation involves the diffusion of identical or similar consumption patterns in a supra-national dimension. What favours the globalisation processes is the homogenisation of consumption, expressed in the unification of its level and structure in the spatial and socio-occupational cross-sections of private households. A convergence of consumption ensues, on the substrate of global processes. Important factors stimulating the homogenisation processes include the emergence of the so-called global production and consumption culture, increased spatial and socio-occupational mobility of people, and dynamic growth of large cities and conurbations. Moreover, the processes of homogenisation of consumption are also accelerated by the standardisation of products and the development of trans-national corporations and online communication. The homogenisation of lifestyles of people in the demographic and social cross-sections contribute to the global convergence of consumption as well. The blurring of distinctions between the people's life styles occurs on various planes. What is most symptomatic of our times, is the shifting of the borders of nations, and social and racial affiliations. The convergence of people's behavioural patterns also takes place in the social and demographic dimensions. The changes taking place in consumption result in an intensifying global detraditionalisation. This trend is expressed in the reduced roles of local, occupational, and family traditions in the shaping of consumer behaviour. As shown by the studies carried out in the food market, detraditionalisation did not lead to the unification of consumption patterns there. Instead, there is a clear polarisation between unified and diversified behavioural patterns, corresponding to the ethnocentric attitudes of Poles.

\section{Conclusions}

1) The experiences over 13 years of integration with the EU indicate that the consumption structure in Poland is converging towards the developed countries of the Union. It confirms the assumption that household incomes are still a crucial determinant of the proximity between the transforming countries and the most developed countries of the EU. The convergence of consumption patterns occurs not only in a long-term perspective but is stimulated by the common integration policy as well.

2) While observing the changes in consumption through the lens of demand and different needs of consumers in the European and global dimensions, one should perceive the effect of the processes of globalisation and integration on the reshaping of the behavioural patterns of food consumers, seeking the common denominator for societies regardless of cultural barriers. The globalisation and integration processes lead to the formation of common patterns containing all determinants, as the basis of their convergence, within their structures.

\section{Bibliography}

1. Budgets of Households, (2016), GUS, Warszawa.

2. Bylok, F. (2013). Konsumpcja, konsument i społeczeństwo konsumpcyjne we współczesnym świecie, "Slask”

3. Sp. z o.o. Wydawnictwo Naukowe, Katowice.

4. Bywalec, Cz., Rudnicki I. (2002). Konsumpcja, PWE, Warszawa.

5. Bywalec, Cz. (2010). Konsumpcja a rozwój gospodarczy i społeczny, Wydawnictwo C.H. Beck, Warszawa.

6. Dąbrowska, A., Bylok, F., Janos-Kreslo, M., Kielczewski, D., Ozimek, I., (2015). Kompetencje konsumentow - innowacyjne zachowania -zrownowazona konsumpcja. PWE, Warszawa.

7. Europe in figures, (2015). Eurostat yearbook.

8. Eurostat Newsrelease, (2016). 118/2016/15 June 2016

9. Eurostat Newsrelease, (2017). 91/2017/13 June 2017 
10. Janos-Kreslo, M, Mroz, B., (2006). Konsument i konsumpcja w gospodarce rynkowej. SGH, Warszawa.

11. Kwasek, M., (2012). Wzorce konsumpcji zywnosci w Polsce. Studia i Monografie. IERiGz. Warszawa.

12. Maslov, A.M., 1990. Motywacja I osobowosc. Instytut Wydawniczy PAX. Warszawa.

13. Matuszewska, I. (1992). Sensoryczne metody ocen konsumenckich - charakterystyka i zastosowanie. Przemysl Spozywczy, 5/6

14. Małysa-Kaleta, A. (2015). Kierunki oraz determinanty zmian struktury konsumpcji w krajach Unii Europejskiej, Studia Ekonomiczne. Zeszyty Naukowe Uniwersytetu Ekonomicznego w Katowicach, Nr 231/ 2015, Katowice.

15. Rocznik Statystyki Miedzynarodowej (2015). Central Statistical Office. Warsaw.

16. Szwacka-Mokrzycka, J., (2015). The Standard of Living of Households in Poland Compared to Other EU Member States. Journal of Advances in Agriculture, November 20/2015.

17. Szwacka-Salmonowicz J., (2003). Zmiany zachowań nabywców jako determinanta kształtowania strategii segmentacyjnych przedsiebiorstw przemyslu spozywczego w Polsce. Wydawnictwo SGGW, Warszawa.

18. Szwacka-Mokrzycka J., (2013). Tendencje rozwojowe popytu i podaży żywności w Polsce. Wydawnictwo SGGW, Warszawa.

19. Szczepanski J. (1981), Konsumpcja a rozwoj człowieka. Wstęp do antropologicznej teorii konsumpcji, PWE, Warszawa.

20. Zielinska Z., (1978). Wspolczynniki elastycznosci dochodowej jako mierniki przemian w strukturze spozycia zywności w Polsce, Handel Wewnętrzny nr 5. 